\title{
Lung function and respiratory symptoms in pig
} farmers

\author{
P BONGERS, ${ }^{1}$ D HOUTHUIJS, ${ }^{2}$ B REMIJN, ${ }^{1}$ R BROUWER, ${ }^{1}$ K BIERSTEKER ${ }^{1}$ \\ From the Departments of Environmental and Tropical Health ${ }^{1}$ and Air Pollution, ${ }^{2}$ Agricultural University of \\ Wageningen, 6703 BM Wageningen, The Netherlands
}

ABSTRACT In a pilot study to investigate the health effects of swine confinement work on the respiratory tract pulmonary function tests and a questionnaire for respiratory symptoms were used. Complete data, including qualitative exposure information, were gathered for 132 owners of fattening, breeding, or closed pig farms. All measured pulmonary function values, except the FVC, were on average lower than the reference values of the European Committee for Coal and Steel. There were no significant associations between duration of exposure and pulmonary function. About $28 \%$ of the farmers had respiratory or flu-like symptoms during or shortly after confinement work; $14 \%$ reported symptoms four to eight hours after work. For the fattening farm the following elements of confinement management were negatively correlated with pulmonary function: fully slatted floor, an automatic feeding system, natural ventilation, and the use of dust masks. A significant association between lung disease of the pigs and pulmonary function of the pig farmers was observed.

In the past 20 years pig farming has been one of the fastest growing agrarian professions in The Netherlands, especially in the southern and eastern regions, with sandy soils, where traditionally farms were small.

Few Dutch data were available about work related health effects of swine confinement work. ${ }^{12}$ Willems et al used a postal questionnaire to study the health of 1895 Dutch agricultural workers. ${ }^{1}$ The 143 pig farmers of this group reported more complaints about dust than most other agricultural groups. Ten per cent reported symptoms of daily cough and phlegm during three months or more a year and $6 \%$ reported tightness of the chest. ${ }^{2}$ The results of studies in the United States showed much higher prevalences of respiratory symptoms. ${ }^{3-6}$ About $70 \%$ chronic cough, $60 \%$ phlegm, and $60 \%$ asthma were reported when standardised questionnaires were not used. ${ }^{35}$ The use of the American Thoracic Society questionnaire showed that 24 confinement workers experienced significant higher prevalences of chronic bronchitis and wheezing, ${ }^{7}$ compared with 24 controls. ${ }^{6}$ The results of studies on the effect of swine confinement work on the pulmonary function are conflicting. American studies showed no significant differences in baseline pulmonary function between

Accepted 10 November 1986
24 confinement workers and 24 controls but in 21 workers a 3-12\% decline in pulmonary function over a four hour work period was found. ${ }^{6} 8$ Twenty nine Swedish pig farmers had a mean $\mathrm{FEV}_{1}$ before work that was significantly lower than predicted. There was no change in $\mathrm{FEV}_{1}$ over the workshift. ${ }^{9}$

Inside the confinement units high concentrations of carbon monoxide, carbon dioxide, hydrogen sulphide, ammonia, and dust have been reported, sometimes exceeding internationally accepted TLVs. ${ }^{310-12}$ The dust particles consist of a broad range of compounds including bacteria, fungi, mould spores, endotoxin, dried faecal matter, hair, animal skin, and organic dusts, which are associated with cellular responses and indirectly with flu-like symptoms and lung disease. ${ }^{3913-20}$

Dutch veterinary publications have reported that some characteristics of the confinement design are related to the prevalence of lung disease among the pigs. ${ }^{21} 22$ Lung pathology of the fattening pigs is registered at the slaughterhouse. The following factors were associated with a high percentage of lung disease in the pigs: little space per pig, many pigs per compartment, location of the pigs alongside a central corridor (as opposed to separate units transverse on a central corridor), and the continuous intake system (as opposed to the "all in all out" system). This raised the question whether lung symptoms of the Dutch farmers might be related to the same factors. 


\section{Methods}

The pig farmers were selected by the "Landbouwschap," the national farmers association. They lived in the southeast of the Netherlands. Only those farmers in the region who were male, between 25 and 65 , and whose income was over $50 \%$ dependent on pigs were selected. An invitation was sent to $198 \mathrm{farm}$ ers and $160(81 \%)$ responded by appearing at the Occupational Health Service in Boxmeer for a physical check up.

Pulmonary function test data were collected with a dry spirometer (Vicatest-4) according to the protocol of the European Committee for Coal and Steel (ECCS). ${ }^{23}$ The following parameters were registered: FVC, FEV $_{1}$, PEF, $\mathrm{MEF}_{75 \%}, \mathrm{MEF}_{50 \%}, \mathrm{MEF}_{25 \%}$, and MMEF. Because of the slow response of the spirometer, the PEF and $M F_{75 \%}$ were not used for statistical analysis. The tests were conducted between 1300 and 1700 and the spirometer was calibrated each day before and after the tests.

The prevalence of respiratory symptoms was recorded with a short respiratory questionnaire, ${ }^{24}$ which consists of items from an international accepted questionnaire. ${ }^{7}$ Delayed symptoms resulting from cellular response after confinement work were also asked for and recorded. Information on working conditions, design of the confinement buildings, exposure time (h/day), and duration of exposure (years) was also gathered on the questionnaire.

Not all participants were included in the statistical analysis in order to exclude some of the confounding elements for which it was not possible to adjust in the statistical analysis. Those who had a lung disease due to other causes than pig farming were not included nor, because of their small number, were farm labourers: 132 pig farm owners with a complete set of data remained for statistical analyses.

The results of the pulmonary function tests were compared with the reference values of the ECCS. The relation between pulmonary function and exposure was analysed by multiple regression techniques.

Pig farms in the Netherlands may be divided into three categories: fattening, breeding, and closed (breeding and fattening at the same farm). Some of the results are presented separately for each of these subpopulations.

\section{Results}

SOME CHARACTERISTICS OF THE POPULATION It turned out that several farmers did not have pigs only: $54 \%$ also had cattle and $7 \%$ had pigs and poultry. Of the 132 participants, 62 had a fattening farm, 42 a breeding farm, and 28 a closed system. The fattening farms had on average 449 pigs, the breeding
Table 1 Mean and standard deviation (SD) of age, height, weight, and pulmonary function parameters of 132 pig farmers. Residual pulmonary function values computed per person by subtracting ECCS reference value from measured value

\begin{tabular}{lccc}
\hline Parameter & Mean & SD & Residual value \\
\hline Age (year) & 47.1 & 10.8 & \\
Height (m) & 1.74 & 0.06 & \\
Weight (kg) & 76.1 & 8.4 & \\
FVC (1) & 4.61 & 0.9 & $0.16^{* *}$ \\
FEV $_{1}(1)$ & 3.53 & 0.9 & $-0.09^{* *}$ \\
MEF $_{\text {s0\% (1/s) }}$ & 4.28 & 1.8 & $-0.51^{* *}$ \\
MEF $_{25 \%}(1 / \mathrm{s})$ & 1.57 & 0.8 & $-0.40^{* *}$ \\
MMEF $(1 / \mathrm{s})$ & 3.34 & 1.4 & $-0.71^{* *}$ \\
\hline
\end{tabular}

${ }^{* *} \mathrm{p}<0.05 t$ test (two sided).

farms 92 sows. The fattening farmers spent less time inside the confinement houses than the breeding $\doteq$ farmers. The owners of a closed farm spent less time $\vec{N}$ per swine inside the confinement building. This type $\infty$ of farm is relatively modern. These farmers had on $\overrightarrow{0}$ average been engaged in swine keeping for 20 years 울 compared with 28 years for the fattening and breeding farmers.

\section{PULMONARY FUNCTION TESTS}

The pulmonary function data were compared with $\underset{\mathbb{\Phi}}{\overparen{D}}$ the ECCS reference values. Table 1 shows the mean age, height, weight, and pulmonary function value $\underset{\varnothing}{œ}$ Residual values were computed by comparing the ECCS values, based on age and height, with the mexis. sured values for each person. Student's $t$ test was use to detect significant differences. Except for the FVC the measured functions for the total group were on average significantly lower than expected (table 1).

In the multiple regression analysis of the relation $\overrightarrow{\vec{P}}$ between pulmonary function and exposure variables, $\frac{\circ}{3}$ pulmonary function was adjusted for age, duration, smoking, and previous occupational exposure to irritating chemicals.

Fatteners, breeders, and closed system farmers did not differ significantly in pulmonary function. We found no relation between pulmonary function and hours a day spent inside the confinement building. Because of the high correlation $(r>0.8)$ between total years of farming and age of the farmer, it was not possible to interpret the influence of duration of exposure on pulmonary function.

A significant association was found, however, between some characteristics of the confinement $\mathcal{N}$ systems and the pulmonary function values of the fatteners (table 2). Mechanical ventilation of the $O$ buildings and hand feeding had a positive influence $\mathrm{\omega}$ on pulmonary function. Although only significant for the MMEF, a fully slatted floor seemed to have an 0 adverse effect. The use of dust masks was negatively associated with the pulmonary function. These 
Table 2 Differences in pulmonary function of fattening farmers dependent on characteristics of the confinement system. Pulmonary function adjusted for age, height, smoking, and exposure to irritating chemicals $(n=62)$

\begin{tabular}{|c|c|c|c|c|c|}
\hline \multirow[b]{2}{*}{ Confinement characteristics } & \multicolumn{5}{|c|}{ Difference $†$} \\
\hline & $F V C(l)$ & $F E V_{1}(l)$ & $M E F_{50 \%}(l / s)$ & $M E F_{25 \%}(l / s)$ & $M M E F(l / s)$ \\
\hline $\begin{array}{l}\text { Fully slatted floor } \\
\text { All in all out } \\
\text { Transverse formation } \\
\text { Feeding by hand } \\
\text { Dust reducing measurements } \\
\text { Use of dust masks } \\
\text { Mechanical ventilation }\end{array}$ & $\begin{array}{r}0.18 \\
-0.13 \\
-0.13 \\
0.29 \\
-0.12 \\
-0.14 \\
0.35\end{array}$ & $\begin{array}{l}-0.10 \\
-0.13 \\
0.11 \\
0.44^{* *} \\
0.16 \\
-0.33^{* *} \\
0.67^{* *}\end{array}$ & $\begin{array}{l}-0.67 \\
-0 \cdot 25 \\
0 \cdot 51 \\
1 \cdot 12^{* *} \\
0.60 \\
-1 \cdot 00^{*} \\
1 \cdot 63^{* *}\end{array}$ & $\begin{array}{l}-0.35 \\
0.08 \\
0.08 \\
0.03 \\
0.10 \\
-0.73^{* *} \\
0.55\end{array}$ & $\begin{array}{l}-0.68^{*} \\
-0 \cdot 11 \\
0.26 \\
0.74^{*} \\
-0.49 \\
-0.92^{* *} \\
1 \cdot 36^{* *}\end{array}$ \\
\hline
\end{tabular}

$* \mathrm{p}<0.10$ (two sided test); ${ }^{* *} \mathrm{p}<0.05$ (two sided test).

†Difference is equal to multiple regression coefficient of the confinement characteristics $(0 / 1)$.

Table 3 Differences in pulmonary function between fatteners with $10 \%$ and $30 \%$ pigs with lung disease. Pulmonary function adjusted for age, height, smoking, and exposure to irritating chemicals $(n=38) \dagger$

\begin{tabular}{ll}
\hline Pulmonary function & Difference \\
\hline FVC (1) & -0.08 \\
FEV $_{1}(1)$ & $-0.26^{* *}$ \\
MEF $_{50 \%}(1 / \mathrm{s})$ & $-0.72^{* *}$ \\
MEF $_{25 \%}(1 / \mathrm{s})$ & $-0 \cdot 22$ \\
MMEF $(1 / \mathrm{s})$ & $-0.48^{*}$ \\
\hline
\end{tabular}

${ }^{*} \mathrm{p}<0.10$ (one sided test); ${ }^{* *} \mathrm{p}<0.05$ (one sided test).

tOnly for 38 of the 62 fattening farms was the lung pathology of the pigs known.

significant relations were found only for the fattening farms, no such associations were found for the other subpopulations.

The data in table 3 show that there was a significant negative association between the pulmonary function of the fatteners and the postmortem percentage lung diseases of their pigs. In table 3 the results of the multiple regressions are presented as differences between fattening farmers with $10 \%$ (low) and with $30 \%$ (high) pigs with lung disease.

\section{RES PIRA TOR Y SYM PTOMS}

The prevalence of respiratory symptoms is presented in table 4 . The differences in respiratory complaints between the three subgroups were tested with the $\chi^{2}$-test. Owners of the breeding farms reported slightly more chronic phlegm than the others. All other respiratory symptoms were comparable among the three groups. About $28 \%$ of the pig farmers reported one or more complaints during or shortly after work; $14 \%$ still reported adverse symptoms four to eight hours later (table 5).

Shortness of breath during or shortly after work inside the confinement house was significantly more prevalent in owners of closed farms; phlegm four to eight hours after confinement work was significantly more prevalent among owners of sows only (not shown). Hardly any of the farmers reported delayed symptoms such as fever, malaise, or heavy sweating (table 5).

Because of the small groups, multivariate analysis of the relation between symptoms and exposure parameters was not possible.

\section{Summary and discussion}

The main objective of this feasibility study was to explore correlations between pulmonary health and work environment of pig farmers in the Netherlands. No previous studies were available.

Many of the pig farmers studied also had other types of agriculture activities $(60 \%)$. This means that they were not only exposed to the air inside the pig house but potentially to other health risks also. In

Table 4 Prevalence of respiratory symptoms in 132 pig farmers

\begin{tabular}{|c|c|c|c|c|}
\hline & $\begin{array}{l}\text { Total } \\
(n=132)(\%)\end{array}$ & $\begin{array}{l}\text { Pig fattening } \\
(n=62)(\%)\end{array}$ & $\begin{array}{l}\text { Pig breeding } \\
(n=42)(\%)\end{array}$ & $\begin{array}{l}\text { Closed pig farm } \\
(n=28)(\%)\end{array}$ \\
\hline $\begin{array}{l}\text { Daily cough }>3 \text { months/year } \\
\text { Daily phlegm }>3 \text { months/year } \\
\text { Shortness of breath } \\
\text { Wheezing } \\
\text { Wheezing for one week } \\
\text { Tightness of chest (asthma) } \\
\text { One or more of these symptoms }\end{array}$ & $\begin{array}{r}9 \cdot 8 \\
5 \cdot 3 \\
9 \cdot 8 \\
12 \cdot 9 \\
4 \cdot 5 \\
6 \cdot 1 \\
22 \cdot 6\end{array}$ & $\begin{array}{r}9 \cdot 7 \\
1 \cdot 6 \\
11 \cdot 3 \\
12 \cdot 9 \\
6 \cdot 5 \\
4 \cdot 8 \\
26 \cdot 2\end{array}$ & $\begin{array}{r}11 \cdot 9 \\
11.9 * \\
4 \cdot 8 \\
11.9 \\
4.8 \\
7 \cdot 1 \\
28.6\end{array}$ & $\begin{array}{c}7 \cdot 1 \\
3 \cdot 6 \\
14 \cdot 2 \\
14 \cdot 2 \\
0 \\
7 \cdot 1 \\
25 \cdot 0\end{array}$ \\
\hline
\end{tabular}

${ }^{*} \mathrm{p}<0.10$ (two sided, $\chi^{2}$ test). 
Table 5 Prevalence of respiratory symptoms during or shortly after work and four to eight hours after work inside the confinement houses $(n=132)$

\begin{tabular}{lll}
\hline & $\begin{array}{l}\text { Shortly } \\
\text { after work (\%) }\end{array}$ & $\begin{array}{l}4 \text { to } 8 \text { hours } \\
\text { after work (\%) }\end{array}$ \\
\hline Cough & $16 \cdot 7$ & $9 \cdot 1$ \\
Chest pain & $3 \cdot 0$ & $3 \cdot 0$ \\
Shortness of breath & $8 \cdot 3$ & $5 \cdot 3$ \\
Sputum & $6 \cdot 1$ & $5 \cdot 3$ \\
Nausea & $1 \cdot 5$ & $0 \cdot 8$ \\
Vomiting & $0 \cdot 8$ & $0 \cdot 8$ \\
Headache & $1 \cdot 5$ & 0 \\
Shivering & 0 & 0 \\
Fever & 0 & 0 \\
Strong perspiration & $6 \cdot 1$ & 0 \\
Clogged nose & $7 \cdot 6$ & $0 \cdot 8$ \\
One or more of these symptoms & 28.0 & 13.6 \\
\hline
\end{tabular}

future studies these types of exposure should, if possible, be excluded.

By contrast with industrial workers, a farmer can have some influence on his own work environment. When experiencing adverse health effects it is possible to change the design or management of the confinement operation-for example, using a vacuum cleaner to reduce the dust or someone else to sweep the stables. This makes it difficult to examine the relation between respiratory effects and working conditions. Investigating this relation is also complicated by the great development of the confinement industry in recent years. The new pig farm has far more pigs than several years ago. The farmers often have several types of confinement buildings on their farm, making it difficult to estimate the exposure.

All pulmonary function values, except for the FVC, were on average lower than the ECCS reference values. Comparisons were made between the three categories of pig farmers. No significant differences were found in pulmonary function values. There was also no significant association between duration of exposure and pulmonary function.

Some of the elements of confinement management were correlated with the pulmonary function of the owners of a fattening farm. Having natural instead of mechanical ventilation may have adverse respiratory effects; the same goes for a fully slatted floor. This agrees well with reports on confinement design in relation to the lung diseases of the pigs. ${ }^{2122}$ The negative association between an automatic feeding system and the pulmonary function is unexpected. It seems that such a device does not improve the stall climate. The use of dust masks is significantly correlated with a lower pulmonary function. This relation is probably caused by the fact that people who experience adverse respiratory symptoms start to use respiratory protection.

A significant association between lung disease of the pigs and pulmonary function of the pig farmers $\overline{\overline{2}}$ was observed. Although the lung diseases of the pigs 3 are of a different type than the pulmonary effects $\underset{\propto}{\mathbb{D}}$ investigated in this study, it seems possible that the environment in the confinement buildings has anos adverse effect on the lungs of both the farmers and theo pigs.

About $28 \%$ of the pig farmers experienced adverse $\frac{\overline{\bar{c}}}{\overline{0}}$ symptoms during or shortly after confinement work. $\stackrel{\mathbb{Q}}{\alpha}$ Owners of a closed farm complain more about shortness of breath after work inside the pig house. Ownerss of a breeding farm report more excess phlegm. None. of the farmers reported flu-like symptoms. Donham $\overrightarrow{-}$ reported flu-like symptoms in $12 \%$ of his population. ${ }^{4}$ About $25 \%$ of the people in this study were said to have a cold when questioned. Possibly not all 3 symptoms were reported in relation to the work inside the confinement houses. The farmers themselves often attributed the symptoms experienced to a cold or flu? caused by frequently changing from warm (inside) to $\stackrel{\infty}{\varphi}$ cold (outside) and back.

A further study will focus on the relation between ${ }^{\circ}$ the level of airborne pollutants in the swine $\vec{\square}$ confinement building and the characteristics of theo confinement design and the relation between respira- $\mathbb{\Phi}$ tory health and exposure in swine confinement buildings. Special attention will be paid to exposure to the biological compounds of airborne dust. ${ }^{25}$

This study was restricted to male pig farmers but the Netherlands the farmer's wife often participates the daily farm work. Future investigations showdo include the women in this agricultural profession.

This study would not have been possible without the气

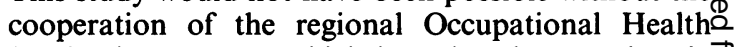
Service in Boxmeer which introduced us to the pig $\overrightarrow{\vec{O}}$ farmers. Especially we thank Sjef van Haaren (direc-3 tor), Huub Smeets, and Annemie Lensen for their? help. Kees Mulder (medical student) was helpful in? interviewing the farmers. We thank Jos van Hutteno for her help with preparing the manuscript.

\section{References}

1 Willems H, Verlinden F, Biersteker K. Work and health of theo Dutch farmer. Tydschrift voor Sociale Gezundheidszorg 1984;62:21-7. (In Dutch, English abstract.)

2 Biersteker K, Willems H, Smid T. A postal survey of health and working conditions of Dutch farmers. In: Proceedings of the 9th International Congress in Agricultural Medicine and Rurab Health, Christchurch, New Zealand, 1984.

3 Donham KJ, Rubino M, Thedall TD, Kammermeyer J. Potentia health hazards to agricultural workers in swine confinemen $\tilde{\omega}$ buildings. J Occup Med 1977;19:383-7.

4 Donham KJ. Respiratory hazards of livestock confinement work ers. In: Proceedings of the VII International Congress of Rurde Medicine, Salt Lake City, 1978. Oakdale Iowa: Institute of Agฐ̄ ricultural Medicine, 1978:224-37. 
5 Donham KJ, Gustafson KE. Human occupational hazards from swine confinement. Annals of the American Conference of Governmental Industrial Hygienists 1982;2:137-44.

6 Donham KJ, Zavala DC, Merchant JA. Respiratory symptoms and lung function among workers in swine confinement buildings. A cross-sectional epidemiological study. Arch Environ Health 1984;39:96-101.

7 Ferris BG. Epidemiology standardisation project. II. Recommended respiratory disease questionnaires for use with adults and children in epidemiological research. Am Rev Respir Dis 1978;118:7-53.

8 Donham KJ, Zavala DC, Merchant J. Acute effects of the work environment on pulmonary functions of swine confinement workers. Am J Ind Med 1984;5:367-75.

9 Haglind $P$, Rylander R. Occupational exposure and lung function measurements among workers in swine confinement buildings. Abstract annual meeting. Am Rev Respir Dis 1984;129:A178.

10 Muehling AJ. Swine housing and waste management: a reseach review. Urbana, Illinois: Co-operative Extension Service, University of Illinois, 1969:65-78. (Publ No AEng-849.)

11 Diesch S. Potential occupational health hazards of livestock producers working in animal confinement units. In: Proceedings of the Society of Occupational and Environmental Health, Conference on agricultural health and safety, Iowa City, 1974. New York: Society for Occupational and Environmental Health, 1974.

12 Donham KJ, Popendorf WJ. Ambient levels of selected gases inside swine confinement buildings. Am Ind Hyg Assoc J 1985;46:658-61.

13 Thedell TD, Mull JC, Olenchock SA. A brief report of Gram negative bacterial endotoxin levels in airborne and settled dusts in animal confinement buildings. Am J Ind Med 1980;1:3-7.

14 Clark S, Rylander R, Larsson L. Airborne bacteria, endotoxin and fungi in dust in poultry and swine confinement buildings. Am Ind Hyg Assoc $J$ 1983;44:537-41.

15 Katila ML, Mäntyljärvi RA, Ojanen TH. Sensitisation against environmental antigens and respiratory symptoms in swine workers. Br J Ind Med 1981;38:334-8.

16 Popendorf W, Donham KJ, Easton DN, Silk J. A synopsis of agricultural respiratory hazards. Am Ind $\mathrm{Hyg}$ Assoc J 1985;46:154-61.

17 Merchant JA. Agricultural respiratory diseases. Seminars in Respiratory Medicine 1986;7:211-24.

18 Dutkiewicz J. Exposure to dust-borne bacteria in agriculture. II. Immunological survey. Arch Environ Health 1978;33:260-70.

19 Rylander R. Organic dusts and lung reactions - exposure characteristics and mechanisms for disease. Scand J Work Environ Health 1985;11:199-206.

20 Brigham KL, Meyrich B. Endotoxin and lung injury. Am Rev Respir Dis 1986;133:913-27.

21 Tielen MJM, Truyen WT, van der Groes CAM, Verstegen MAW, de Bruyn JJM, Conbey RAPH. Conditions of management and construction of the piggeries on pig-fattening farms as factors in the incidence of disease of the lung and liver in slaughtered pigs. Tÿdschrift voor Diergeneeskunde 1978; 21:1155-65. (In Dutch, English abstract.)

22 Groes CAM van de. Confinement design and health on pig fattening farms. Doctoraalscriptie Gezondheidsdienst voor Dieren, Vakgroep Veehouderij, Landbouwhogeschool Wageningen, 1978. (In Dutch.)

23 Quanjer PhH. Standardised lung function testing. Report of the working group "standardization of the lung function" of the European Committee for Coal and Steel, Luxembourg. Bull Europ Physiopathol Respir 1983;19, suppl 5:1-95.

24 Biersteker K, Van Dijk WH, Eissens JBMF, Van Geens HA. The prevalence of CNSLD in male municipal employees in Rotterdam. Tüdschrift voor Sociale Geneeskunde 1974;32:158-62. (In Dutch, English abstract.)

25 Attwood P, Versloot P, Heederik D, Wit R de, Boleij JSM. Assessment of dust and endotoxin levels in the working environment of Dutch pig farmers: a preliminary study. Ann Occup Hyg 1986;30:201-8. 